
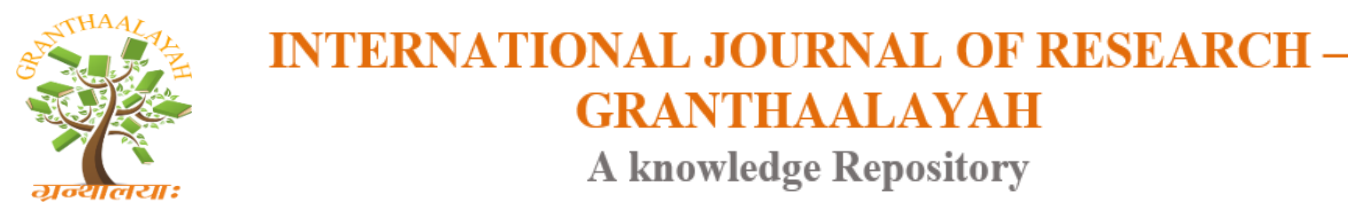

Science

\title{
SURVEY AND DOCUMENTATION OF ETHNOVETERINARY HEALTHCARE PRACTICES USED BY RURAL PEOPLE OF AKOLA DISTRICT OF MAHARASHTRA
}

\author{
Sangeeta Jambu *1, Manjusha Wath ${ }^{2}$ \\ ${ }^{*} 1,2$ Department of Botany, Government Vidarbha Institute of Science and Humanities, Amravati \\ 444604, Maharashtra, India
}

\begin{abstract}
The people of rural areas still depend to a large extent upon plants and household remedies for treating their animals. The present study deals with the survey and documentation of ethno veterinary medicinal plants used by rural people from Akola district. The ethnoveterinary information included with local name, family, parts used, local uses and its mode of preparation for ethnoveterinary treatments. The common cattle diseases of the area reported are foot and mouth diseases, black quarter, fracture, Diarrhoea and Dysentery and dysentery, blood dysentery, intestinal worm, tympani, prolapsed uterus, retention of placenta, wound, maggotted wound, fever, snake bite, eye diseases, ectoparasite (tick), galactagogue etc. In this study we observed that old aged people have more knowledge and experience particularly in remote areas for curing veterinary ailments. Ethnoveterinary medicine can provide an opportunity for new drug development.
\end{abstract}

Keywords: Ethnoveterinary Uses; Medicinal Plants; Veterinary Ailments; Livestock.

Cite This Article: Sangeeta Jambu, and Manjusha Wath. (2018). "SURVEY AND DOCUMENTATION OF ETHNOVETERINARY HEALTHCARE PRACTICES USED BY RURAL PEOPLE OF AKOLA DISTRICT OF MAHARASHTRA.” International Journal of Research - Granthaalayah, 6(1), 306-318. 10.29121/granthaalayah.v6.i1.2018.1621.

\section{Introduction}

The people of rural India still dependent on traditional medicines for their health care and treatment of diseases. Eighty percent of population in the developing countries depends on indigenous practices for treatment of various diseases of both human beings and animals (Balaji and Chakravarti, 2010). Rural India is a rich source of ethnoveterinary medicines. Medicinal plants have been used since long in Indian medicine systems.

Ethnoveterinary Medicine (EVM) deals with the folk beliefs, knowledge, skills, methods and practices pertaining to the health care of animals (Mc Corkle, 1986). The traditional knowledge of ethnoveterinary medicines has been identified by the traditional communities through a 
process of experience over hundreds of years. These practices have been transfer from one generation to next generation by word of mouth. Due to lack of proper records and over exploitation of these plants by local people, the natural resources along with related traditional knowledge are reduce day by day (Roy, 2003).

The traditional system of treatment is one of the most important prevailing systems in the area where modern veterinary health care facilities are rare or in very poor conditions. The documentation of traditional knowledge is valuable for the communities and their future generations and for scientific consideration of wider uses of traditional knowledge in treating livestock. Therefore, it is necessary to record this valuable information for the utilization of community and for the further scientific pursuit.

\section{Study Area}

Akola district is lies between $19^{\circ} 51^{\prime}$ and $21^{\circ} 16^{\prime}$ latitude and $76^{\circ} 38^{\prime}$ and $77^{\circ} 44^{\prime}$ longitude. Akola District has an area of about $5,431 \mathrm{~km} 2$. The Melghat referred as the Satpuda scarp in Vidarbha region of Maharashtra State also forms a very small part within the district. District consists of seven talukas namely Akot, Telhara, Akola, Balapur, Patur, Barshitakli and Murtajapur. The climate of this district is characterised by a hot summer and general dryness throughout the year except during the south-west monsoon season. The mean daily maximum temperature at Akola is $42.4^{\circ} \mathrm{C}$ and the mean daily minimum temperature is $27.5^{\circ} \mathrm{C}$. The average annual rainfall of the district is $846.5 \mathrm{~mm}$. The forest in the district is "South Indian Tropical dry deciduous" type. According to census 2011 total population of Akola district is 1,818,617. The major communities of tribal those reside in the district are Banjara, Jhingabhoi, Pal Pardhi, Bedar, Kannadas, Gopal, Pathrat, Korku and Lonaris etc.

\section{Materials and Methods}

A field survey was conducted in different villages of the Akola district. Data collected through informal discussions, interviews and village walk with informants, medicine men were held to enhance understanding and gather information about different species of medicinal plant available around the villages. The questionnaires were used to obtain information on medicinal plants with their local names, parts, used, mode of preparations and administrations. Plant species were identified with help of floras Cooke (1967), Naik (1998) and Singh and Karthikeyan (2000).

\section{Results and Discussions}

In the present study a total of 93 plant species representing to 83 genera and belonging to 43 families. The plants of ethno-veterinary significance are enumerated in alphabetical sequence (Table: 1) of Botanical Name with family and local name (in parenthesis) followed, plant part used, diseases and mode of administration. A total 139 different plant preparation to treat 22 type of animal diseases. 93 plant species are used in the treatment of different animal diseases and disorders. Majority of preparations from Leaves (47), Underground parts (20), Stem bark (20), Fruits (13), Seeds (19), Whole plant (7) and other (15). 
Table 1: Details of plant species with their ethno-veterinary uses

\begin{tabular}{|c|c|c|c|c|}
\hline $\begin{array}{l}\text { Sr. } \\
\text { no. }\end{array}$ & Botanical name & $\begin{array}{l}\text { Plant } \\
\text { part }\end{array}$ & Diseases & Mode of administration \\
\hline 1 & $\begin{array}{l}\text { Abrus precatorius } \mathrm{L} . \\
\text { Papilionaceae } \\
\text { Gunj }\end{array}$ & Seed & $\begin{array}{l}\text { Retention of } \\
\text { placenta }\end{array}$ & $\begin{array}{l}\text { Paste of } 5 \text { seeds in lukewarm water is } \\
\text { given orally for animal after delivery to } \\
\text { easy removal of placenta. }\end{array}$ \\
\hline 2 & $\begin{array}{l}\text { Aegle marmelos (L.) } \\
\text { Rutaceae } \\
\text { Bel }\end{array}$ & Leaves & $\begin{array}{l}\text { Foot and } \\
\text { mouth diseases }\end{array}$ & $\begin{array}{l}\text { About } 100 \text { gm leaf paste mixed with } \\
\text { honey is applied over mouth of cattle to } \\
\text { cure mouth disease. }\end{array}$ \\
\hline \multirow[t]{2}{*}{3} & \multirow{2}{*}{$\begin{array}{l}\text { Ailanthus excelsa } \\
\text { Roxb. } \\
\text { Simaroubaceae } \\
\text { Maharukh }\end{array}$} & $\begin{array}{l}\text { Stem } \\
\text { bark }\end{array}$ & $\begin{array}{l}\text { Diarrhoea and } \\
\text { Dysentery }\end{array}$ & $\begin{array}{l}100 \text { gm stem bark is pounded in } 1 / 2 \text { litre } \\
\text { butter milk is given orally } 2-4 \text { times a } \\
\text { day to cure diarrhoea. }\end{array}$ \\
\hline & & $\begin{array}{l}\text { Stem } \\
\text { bark }\end{array}$ & Tympani & $\begin{array}{l}100 \text { gm bark pounded with } 1 / 2 \text { litre water } \\
\text { and prepared extract is given orally twice } \\
\text { a day to cure tympani. }\end{array}$ \\
\hline \multirow[t]{3}{*}{4} & \multirow{3}{*}{$\begin{array}{l}\text { Annona squamosa } \mathrm{L} . \\
\text { Annonaceae } \\
\text { Sitaphal }\end{array}$} & Leaves & Wound & $\begin{array}{l}\text { Paste of leaves in water is applied on } \\
\text { wound. }\end{array}$ \\
\hline & & Leaves & $\begin{array}{l}\text { Maggotted } \\
\text { wound }\end{array}$ & $\begin{array}{l}\text { Fresh or dry leaves are crushed with } \\
\text { camphor is applied over maggotted } \\
\text { wound. The seed-paste is also applied to } \\
\text { treat maggotted wound. }\end{array}$ \\
\hline & & Leaves & Ectoparasite & $\begin{array}{l}\text { Leaf extract of the plant is also reported } \\
\text { to be very effective in case of external } \\
\text { parasites. }\end{array}$ \\
\hline \multirow[t]{3}{*}{5} & \multirow{3}{*}{$\begin{array}{l}\text { Argemone mexicana } \\
\text { L. } \\
\text { Papaveraceae } \\
\text { Bilayti }\end{array}$} & Root & $\begin{array}{l}\text { Foot and } \\
\text { mouth diseases }\end{array}$ & $\begin{array}{l}10 \mathrm{gm} \text { roots are ground into cut into } \\
\text { piece immersed inside the bread is fed to } \\
\text { cattle twice a day to cure mouth diseases. }\end{array}$ \\
\hline & & Seed & Tympani & $\begin{array}{l}50 \text { gm of seeds pounded with water is } \\
\text { given orally once in day to cure tympani. }\end{array}$ \\
\hline & & Seed & Wound & $\begin{array}{l}\text { Seed powder is applied externally to cure } \\
\text { wound. }\end{array}$ \\
\hline \multirow[t]{2}{*}{6} & \multirow{2}{*}{$\begin{array}{l}\text { Asparagus } \\
\text { racemosus Willd. } \\
\text { Liliaceae } \\
\text { Asakand }\end{array}$} & Root & Black quarter & $\begin{array}{l}\text { Root is given twice a day to cure black } \\
\text { quarter. }\end{array}$ \\
\hline & & Root & Galactagogue & $\begin{array}{l}\text { The mixture of root powder and wheat } \\
\text { flour is given to the cattle for increasing } \\
\text { milk. }\end{array}$ \\
\hline \multirow[t]{4}{*}{7} & \multirow{4}{*}{$\begin{array}{l}\text { Azadirachta indica } \\
\text { A. Juss. } \\
\text { Meliaceae } \\
\text { Nim }\end{array}$} & Leaves & $\begin{array}{l}\text { Foot and } \\
\text { mouth diseases }\end{array}$ & $\begin{array}{l}\text { Decoction of leaves is used to wash } \\
\text { infected area of cattle to cure foot and } \\
\text { mouth diseases. }\end{array}$ \\
\hline & & Leaves & $\begin{array}{l}\text { Blood } \\
\text { Dysentery }\end{array}$ & $\begin{array}{l}100 \mathrm{ml} \text { decoction of leaves is given } 3 \\
\text { times a day to cure blood dysentery. }\end{array}$ \\
\hline & & Leaves & $\begin{array}{l}\text { Intestinal } \\
\text { worm }\end{array}$ & $\begin{array}{l}\text { Leaf juice is mixed in water is given } \\
\text { orally for expelling intestinal worms. }\end{array}$ \\
\hline & & Leaves & Wound & $\begin{array}{l}\text { Leaves pounded and boiled in water, } \\
\text { lukewarm decoction is used to wash } \\
\text { wound then dried leaf powder spread } \\
\text { externally for quick healing of wound. }\end{array}$ \\
\hline
\end{tabular}




\begin{tabular}{|c|c|c|c|c|}
\hline & & Leaves & Fever & $\begin{array}{l}100 \text { gm leaf extract is given internally to } \\
\text { cure fever. }\end{array}$ \\
\hline \multirow[t]{2}{*}{8} & \multirow[t]{2}{*}{$\begin{array}{l}\text { Bombax ceiba L. } \\
\text { Bombacaceae } \\
\text { Katesaver }\end{array}$} & $\begin{array}{l}\text { Stem } \\
\text { bark }\end{array}$ & Bone fracture & $\begin{array}{l}\text { Stem bark-powder mixed with ant heap } \\
\text { soil luckwarm paste plastered } \\
\text { aroundfracture part and tied with piece of } \\
\text { cloth for early healing. }\end{array}$ \\
\hline & & Stem & $\begin{array}{l}\text { Intestinal } \\
\text { worms }\end{array}$ & $\begin{array}{l}\text { The juice extracted from } 250 \text { gm bark in } \\
\text { cupful of water is given orally once in a } \\
\text { day to expel intestinal worms. }\end{array}$ \\
\hline 9 & $\begin{array}{l}\text { Brassica napus L. } \\
\text { Brassicaceae } \\
\text { Mohair }\end{array}$ & Seed & Mastitis & $\begin{array}{l}100 \text { gm seed powder mixed with } 250 \mathrm{gm} \\
\text { jaggery and the paste is applied over } \\
\text { cracked nipples to treat mastitis. }\end{array}$ \\
\hline \multirow[t]{2}{*}{10} & \multirow{2}{*}{$\begin{array}{l}\text { Caesalpinia bonduc } \\
\text { (L.) } \\
\text { Caesalpiniaceae } \\
\text { Sagargoti }\end{array}$} & Seed & $\begin{array}{l}\text { Intestinal } \\
\text { worms }\end{array}$ & $\begin{array}{l}\text { Decoction of seed powder with water } \\
\text { orally to the cattle suffering from } \\
\text { intestinal worms. }\end{array}$ \\
\hline & & Leaves & Wound & $\begin{array}{l}\text { Dry leaf paste is applied on wound till } \\
\text { healing. }\end{array}$ \\
\hline 11 & $\begin{array}{l}\text { Calotropis gigantea } \\
\text { (L.) } \\
\text { Asclepidaceae } \\
\text { Rue }\end{array}$ & Latex & Wound & $\begin{array}{l}\text { A mixture of latex and red lead applied } \\
\text { on wound. }\end{array}$ \\
\hline \multirow[t]{3}{*}{12} & \multirow{3}{*}{$\begin{array}{l}\text { Calotropis procera } \\
\text { (Ait.) } \\
\text { Asclepidaceae } \\
\text { Rue }\end{array}$} & Leaves & Tympani & $21 / 2$ leaves given orally to cure tympani. \\
\hline & & Latex & Eye diseases & $\begin{array}{l}\text { Five drops latex is mixed with } 1 \\
\text { teaspoon ghee and mixture is applied } \\
\text { externally on infected eyes to cure eye } \\
\text { diseases. }\end{array}$ \\
\hline & & Latex & Swelling & $\begin{array}{l}\text { A strip of rag adhered with sticky latex } \\
\text { and red lead (shindur) is pressed around } \\
\text { swollen area untill cure. }\end{array}$ \\
\hline \multirow[t]{2}{*}{13} & \multirow[t]{2}{*}{$\begin{array}{l}\text { Capparis zeylanica } \\
\text { L. } \\
\text { Capparaceae } \\
\text { Waghota }\end{array}$} & Leaves & Bone fracture & $\begin{array}{l}250 \text { gm leaves crushed in water mixed } \\
\text { with warm ant heap soil, paste prepared } \\
\text { and is plastered around fractured bone } \\
\text { and bandaged with the help of hairs, } \\
\text { cloth strips and bamboo splints. }\end{array}$ \\
\hline & & Leaves & $\begin{array}{l}\text { Diarrhoea and } \\
\text { Dysentery }\end{array}$ & $\begin{array}{l}\text { Leaves are given as feedstuff for } 2-3 \\
\text { days in diarrhoea. }\end{array}$ \\
\hline \multirow[t]{2}{*}{15} & \multirow{2}{*}{$\begin{array}{l}\text { Capsicum annuum } \\
\text { L. } \\
\text { Solanaceae } \\
\text { Mirachi }\end{array}$} & Fruit & $\begin{array}{l}\text { Mouth } \\
\text { diseases }\end{array}$ & $\begin{array}{l}\text { Fruit paste is given orally in mouth } \\
\text { diseases. }\end{array}$ \\
\hline & & Fruit & Snake bite & $\begin{array}{l}\text { Fruit are fed to the cattle in case of snake } \\
\text { bite. }\end{array}$ \\
\hline 16 & $\begin{array}{l}\text { Cassia auriculata } \mathrm{L} . \\
\text { Caesalpiniaceae } \\
\text { Tarod }\end{array}$ & Leaves & $\begin{array}{l}\text { Diarrhoea and } \\
\text { Dysentery }\end{array}$ & $\begin{array}{l}250 \mathrm{ml} \text { leaf juice is given to cattle twice } \\
\text { a day to cure blood dysentery. } 100 \mathrm{gm} \\
\text { tender shoot tip crushed with } 50 \mathrm{gm} \\
\text { butter and jaggery given to cure blood } \\
\text { dysentery. }\end{array}$ \\
\hline 17 & $\begin{array}{l}\text { Cassia fistula } \mathrm{L} . \\
\text { Caesalpiniaceae } \\
\text { Bahava }\end{array}$ & Stem & $\begin{array}{l}\text { Diarrhoea and } \\
\text { Dysentery }\end{array}$ & $\begin{array}{l}50 \text { gm stem paste and salt boiled in } 1 \\
\text { litre water, prepared decoction is given } \\
\text { twice a day orally in case of diarrhoea. }\end{array}$ \\
\hline
\end{tabular}




\begin{tabular}{|c|c|c|c|c|}
\hline & & $\begin{array}{l}\text { Stem } \\
\text { bark }\end{array}$ & Snakebite & $\begin{array}{l}\text { The bark juice mixed with water is given } \\
\text { orally to treat snakebite. }\end{array}$ \\
\hline & & Fruit & Swelling & $\begin{array}{l}\text { Heated fruit applied on affected area to } \\
\text { get relief from swelling. }\end{array}$ \\
\hline 18 & $\begin{array}{l}\text { Cassia obtusifolia L. } \\
\text { Caesalpiniaceae } \\
\text { Tarota }\end{array}$ & Leaves & $\begin{array}{l}\text { Diarrhoea and } \\
\text { Dysentery }\end{array}$ & $\begin{array}{l}100 \mathrm{ml} \text { decoction of leaves mixed with } \\
\text { common salt is given orally to cure } \\
\text { dysentery. }\end{array}$ \\
\hline 19 & $\begin{array}{l}\text { Cassia occidentalis } \\
\text { L. } \\
\text { Caesalpiniaceae } \\
\text { Devtarota }\end{array}$ & Leaves & $\begin{array}{l}\text { Diarrhoea and } \\
\text { Dysentery }\end{array}$ & $\begin{array}{l}\text { Leaves are fed with fodder to cattle to } \\
\text { cure dysentery. }\end{array}$ \\
\hline \multirow[t]{2}{*}{20} & \multirow{2}{*}{$\begin{array}{l}\text { Cayratia trifolia }(\mathrm{L} .) \\
\text { Vitaceae } \\
\text { Kumbbhela }\end{array}$} & Fruit & Fever & $\begin{array}{l}100 \mathrm{gm} \text { paste of fruit is mixed with water } \\
\text { is given orally to cure fever. }\end{array}$ \\
\hline & & Root & Tonic & $\begin{array}{l}100 \mathrm{ml} \text { root extract is given as tonic to } \\
\text { the cattle. }\end{array}$ \\
\hline 21 & $\begin{array}{l}\text { Cissus } \\
\text { quadrangularis L. } \\
\text { Vitaceae } \\
\text { Hadjul }\end{array}$ & Stem & Bone fracture & $\begin{array}{l}\text { Stem crushed in water and paste applied } \\
\text { on fracture area and tied with stick of } \\
\text { bamboo. }\end{array}$ \\
\hline \multirow[t]{2}{*}{22} & \multirow{2}{*}{$\begin{array}{l}\text { Citrullus colocynthis } \\
\text { (L.) } \\
\text { Cucurbitaceae } \\
\text { Kaduedrayan }\end{array}$} & Seed & Tympani & $\begin{array}{l}20 \text { gm seeds powder crushed with water } \\
\text { is given to the animal twice in a day in } \\
\text { case of tympani. }\end{array}$ \\
\hline & & Seed & $\begin{array}{l}\text { Retention of } \\
\text { placenta }\end{array}$ & $\begin{array}{l}\text { Equal amount of seeds and jaggery } \\
\text { mixed with } 250 \text { gm ginger is given to the } \\
\text { animal to easy expulsion of placenta. }\end{array}$ \\
\hline \multirow[t]{3}{*}{23} & \multirow{3}{*}{$\begin{array}{l}\text { Citrus aurantifolia } \\
\text { (Christm.) } \\
\text { Rutaceae } \\
\text { Nimbu }\end{array}$} & Fruit & Mastitis & $\begin{array}{l}\text { Warm fruit juice mixed with indigo is } \\
\text { applied to udder to cure the swelling of } \\
\text { teats (nipple). }\end{array}$ \\
\hline & & Fruit & Eye diseases & $\begin{array}{l}\text { The filtered fruit juice is used to pour in } \\
\text { eyes twice a day to treat eye diseases. }\end{array}$ \\
\hline & & Fruit & Eye diseases & $\begin{array}{l}\text { Mixture of fruit juice and alum is } \\
\text { dropped to the eyes to treat general eye } \\
\text { problem. }\end{array}$ \\
\hline 24 & $\begin{array}{l}\text { Colocasia esculenta } \\
\text { (L.) } \\
\text { Arecaceae } \\
\text { Alu }\end{array}$ & Leaves & Infertility & $\begin{array}{l}\text { Leaves are fed with fodder to cattle in } \\
\text { case of infertility. }\end{array}$ \\
\hline 25 & $\begin{array}{l}\text { Convolvulus } \\
\text { arvensis } \mathrm{L} . \\
\text { Convolvululaceae } \\
\text { Chandvel }\end{array}$ & Root & $\begin{array}{l}\text { Maggotted } \\
\text { wound }\end{array}$ & $\begin{array}{l}\text { Root paste is applied on wound to } \\
\text { destroy maggot. }\end{array}$ \\
\hline 26 & $\begin{array}{l}\text { Corallocarpus } \\
\text { epigaeus } \\
\text { (Rottl. \& Willd.) } \\
\text { Cucurbitaceae } \\
\text { Mirachikand }\end{array}$ & Bulb & $\begin{array}{l}\text { Prolapsed of } \\
\text { uterus }\end{array}$ & $\begin{array}{l}\text { Overnight soaked bulb in animal urine, } \\
\text { crushed and applied on uterus to the } \\
\text { animal suffering from prolapsed of } \\
\text { uterus. }\end{array}$ \\
\hline
\end{tabular}




\begin{tabular}{|c|c|c|c|c|}
\hline 27 & $\begin{array}{l}\text { Cordia dichotoma } \\
\text { Forst. } \\
\text { Ehretiaceae } \\
\text { Gondhan }\end{array}$ & Bark & Bone fracture & $\begin{array}{l}11 / 2 \mathrm{~kg} \text { bark powder, } 250 \text { gm of brick } \\
\text { powder, } 10 \text { gm of hairs and } 125 \mathrm{ml} \\
\text { cooking oil pounded and prepared paste } \\
\text { is applied over fractured bone and } \\
\text { bandaged with the cloth strip. }\end{array}$ \\
\hline \multirow[t]{2}{*}{28} & \multirow{2}{*}{$\begin{array}{l}\text { Coriandrum sativum } \\
\text { L. } \\
\text { Apiaceae } \\
\text { Dhania }\end{array}$} & $\begin{array}{l}\text { Whole } \\
\text { plant }\end{array}$ & $\begin{array}{l}\text { Foot and } \\
\text { mouth diseases }\end{array}$ & $\begin{array}{l}\text { Whole plant is fed along with fodder to } \\
\text { treat foot and mouth diseases. }\end{array}$ \\
\hline & & Seed & $\begin{array}{l}\text { Diarrhoea and } \\
\text { Dysentery }\end{array}$ & $\begin{array}{l}250 \text { gm dried seed powder mixed with } \\
\text { water is given orally twice in day for } \\
\text { three days to cure diarrhoea. }\end{array}$ \\
\hline 29 & $\begin{array}{l}\text { Cuminum cyminum } \\
\text { L. } \\
\text { Apiaceae } \\
\text { Jire }\end{array}$ & Seed & Fever & $\begin{array}{l}100 \text { gm seed powder boiled with water } \\
\text { and prepared decoction is given twice a } \\
\text { day to cure fever. }\end{array}$ \\
\hline \multirow[t]{3}{*}{30} & \multirow{3}{*}{$\begin{array}{l}\text { Curcuma amada } \\
\text { Roxb. } \\
\text { Zingiberaceae } \\
\text { Aambehaladi }\end{array}$} & Rhizome & Bone fracture & $\begin{array}{l}\text { Paste of rhizome is applied topically on } \\
\text { fracture bone and bandaged with cotton } \\
\text { cloth. }\end{array}$ \\
\hline & & Rhizome & Tympani & $\begin{array}{l}\text { One teaspoon rhizome powder, } 100 \text { gm } \\
\text { of jaggery, } 2 \text { gm alum mixed with water } \\
\text { is given to cure tympani. }\end{array}$ \\
\hline & & Rhizome & $\begin{array}{l}\text { Foot and } \\
\text { mouth diseases }\end{array}$ & $\begin{array}{l}50 \text { gm rhizome powder mixed with } 100 \\
\text { ml cooking oil and } 100 \text { gm jaggery is } \\
\text { applied on infected area of mouth } 2-3 \\
\text { times in day to cure mouth diseases. }\end{array}$ \\
\hline \multirow[t]{2}{*}{31} & \multirow[t]{2}{*}{$\begin{array}{l}\text { Curcuma longa L. } \\
\text { Zingiberaceae } \\
\text { Haladi }\end{array}$} & Rhizome & $\begin{array}{l}\text { Foot and } \\
\text { mouth diseases }\end{array}$ & $\begin{array}{l}100 \text { gm rhizome powder mixed with } 100 \\
\text { gm butter is applied on tongue to cure } \\
\text { mouth diseases. }\end{array}$ \\
\hline & & Rhizome & Wound & $\begin{array}{l}\text { An ointment, prepared from rhizome } \\
\text { powder in cooking oil is applied on } \\
\text { Wound. }\end{array}$ \\
\hline 32 & $\begin{array}{l}\text { Cuscuta chinensis } \\
\text { Lamk. } \\
\text { Cuscutaceae } \\
\text { Amarvel }\end{array}$ & Stem & Galactagogue & $\begin{array}{l}\text { Animals are fed with stem to increase the } \\
\text { milk production. }\end{array}$ \\
\hline 33 & $\begin{array}{l}\text { Dalbergia sissoo } \\
\text { Roxb. } \\
\text { Papilionaceae } \\
\text { Shisam }\end{array}$ & Leaves & Diarrhoea & $\begin{array}{l}\text { Leaves ground with butter milk and } \\
\text { given twice a day to cure blood } \\
\text { diarrhoea. }\end{array}$ \\
\hline 34 & $\begin{array}{l}\text { Datura inoxia Mill. } \\
\text { Solanaceae } \\
\text { Dhotra }\end{array}$ & Leaves & Swelling & A warm leaf is tied on swollen area. \\
\hline 35 & $\begin{array}{l}\text { Datura metal L. } \\
\text { Solanaceae } \\
\text { Kaladhotra }\end{array}$ & Leaves & Black quarter & $\begin{array}{l}\text { Leaf paste is applied on leg to cure black } \\
\text { quarter. }\end{array}$ \\
\hline 36 & $\begin{array}{l}\text { Dioscorea bulbifera } \\
\text { L. } \\
\text { Dioscoreaceae } \\
\text { Dukkarkand }\end{array}$ & Bulb & $\begin{array}{l}\text { Prolapsed of } \\
\text { uterus }\end{array}$ & $\begin{array}{l}\text { Overnight soaked bulb in animal urine, } \\
\text { crushed and applied on uterus to the } \\
\text { animal suffering from prolapsed uterus. }\end{array}$ \\
\hline
\end{tabular}




\begin{tabular}{|c|c|c|c|c|}
\hline \multirow[t]{2}{*}{37} & \multirow{2}{*}{$\begin{array}{l}\text { Eucalyptus globulus } \\
\text { Labill. } \\
\text { Myrtaceae } \\
\text { Nilgiri }\end{array}$} & Leaves & Twisted leg & Warm leaves are tied on twisted leg. \\
\hline & & Oil & $\begin{array}{l}\text { Maggotted } \\
\text { wound }\end{array}$ & $\begin{array}{l}\text { Oil is applied on wound to kill the } \\
\text { worms. }\end{array}$ \\
\hline \multirow[t]{2}{*}{38} & \multirow{2}{*}{$\begin{array}{l}\text { Euphorbia prostrata } \\
\text { Ait. } \\
\text { Euphorbiaceae } \\
\text { Gondhan }\end{array}$} & $\begin{array}{l}\text { Whole } \\
\text { plant }\end{array}$ & $\begin{array}{l}\text { Diarrhoea and } \\
\text { Dysentery }\end{array}$ & $\begin{array}{l}250 \text { gm whole plant pounded with butter } \\
\text { milk is given orally thrice a day to cure } \\
\text { dysentery. }\end{array}$ \\
\hline & & $\begin{array}{l}\text { Whole } \\
\text { plant }\end{array}$ & Wound & Crushed whole plant is applied on wound \\
\hline \multirow[t]{2}{*}{39} & \multirow{2}{*}{$\begin{array}{l}\text { Ficus racemosa } \mathrm{L} \text {. } \\
\text { Moraceae } \\
\text { Umber }\end{array}$} & Fruit & $\begin{array}{l}\text { Retention of } \\
\text { placenta }\end{array}$ & $\begin{array}{l}\text { One kg fruit are fed after delivery to } \\
\text { facilitate the removal of placenta. }\end{array}$ \\
\hline & & Stem & Snake bite & $\begin{array}{l}\text { Infusion of } 250 \mathrm{gm} \text { stem in } 1 \text { litre water } \\
\text { is given orally } 3-4 \text { times a day in case of } \\
\text { snake bite. }\end{array}$ \\
\hline 40 & $\begin{array}{l}\text { Ficus religiosa } \mathrm{L} . \\
\text { Moraceae } \\
\text { Pinpal }\end{array}$ & Gum & Snake bite & $\begin{array}{l}\text { Gum of the plant is applied on snake bite } \\
\text { area. }\end{array}$ \\
\hline \multirow[t]{2}{*}{41} & \multirow{2}{*}{$\begin{array}{l}\text { Gardenia resinifera } \\
\text { Roth. } \\
\text { Rubiaceae } \\
\text { Dikamali }\end{array}$} & Resin & $\begin{array}{l}\text { Foot and } \\
\text { mouth diseases }\end{array}$ & $\begin{array}{l}\text { One gm resin boiled with } 250 \mathrm{ml} \text { of } \\
\text { cooking oil is applied on infected area of } \\
\text { foot to cure foot diseases. }\end{array}$ \\
\hline & & Resin & Bone fracture & $\begin{array}{l}\text { Nearly } 2 \text { gm resin mixed with egg } \\
\text { albumin applied externally on fracture } \\
\text { part. }\end{array}$ \\
\hline \multirow[t]{3}{*}{42} & \multirow{3}{*}{$\begin{array}{l}\text { Gloriosa superba L. } \\
\text { Liliaceae } \\
\text { Kallai }\end{array}$} & Root & $\begin{array}{l}\text { Prolapsed of } \\
\text { uterus }\end{array}$ & $\begin{array}{l}\text { Roots are fed to the cattle in case of } \\
\text { prolapsed uterus. }\end{array}$ \\
\hline & & Root & Wound & $\begin{array}{l}\text { Freshly prepared root paste is applied on } \\
\text { wound. }\end{array}$ \\
\hline & & Root & Galactagogue & $\begin{array}{l}2 \text { gm shade dried root powder is fed to } \\
\text { cattle for seven days after delivery to } \\
\text { improve lactation quality. }\end{array}$ \\
\hline 43 & $\begin{array}{l}\text { Gossypium hirsutum } \\
\text { L. } \\
\text { Malvaceae } \\
\text { Kapus }\end{array}$ & Floss & Wound & $\begin{array}{l}\text { Ash of white floss mixed with coconut } \\
\text { oil is applied externally on wound. }\end{array}$ \\
\hline 44 & $\begin{array}{l}\text { Helicteres isora } \mathrm{L} . \\
\text { Sterculiaceae } \\
\text { Muradsheng }\end{array}$ & Root & $\begin{array}{l}\text { Diarrhoea and } \\
\text { Dysentery }\end{array}$ & $\begin{array}{l}50 \text { gm roots soaked overnight in water } \\
\text { and extract is given orally } 2 \text { times a day } \\
\text { to cure dysentery. }\end{array}$ \\
\hline \multirow[t]{2}{*}{45} & \multirow{2}{*}{$\begin{array}{l}\text { Hibiscus cannabinus } \\
\text { L. } \\
\text { Malvaceae } \\
\text { Ambadi }\end{array}$} & Leaves & Haematuria & $\begin{array}{l}\text { Dry leaves are used as fodder to control } \\
\text { haematuria. }\end{array}$ \\
\hline & & Leaves & $\begin{array}{l}\text { Retention of } \\
\text { placenta }\end{array}$ & $\begin{array}{l}\text { Leaves are fed to cattle to hasten } \\
\text { placental discharge following delivery. } \\
\text { Dried leaves powder and jawar bread } \\
\text { (bhakari) is also given orally to cattle } \\
\text { after delivery for easy discharge of } \\
\text { placenta. }\end{array}$ \\
\hline 46 & $\begin{array}{l}\text { Holarrhena } \\
\text { pubescens }\end{array}$ & Bark & $\begin{array}{l}\text { Diarrhoea and } \\
\text { Dysentery }\end{array}$ & $\begin{array}{l}100 \mathrm{gm} \text { bark paste soaked overnight in } \\
\text { water; the extract is given orally to cattle }\end{array}$ \\
\hline
\end{tabular}




\begin{tabular}{|c|c|c|c|c|}
\hline & $\begin{array}{l}\text { (Buch.-Ham.) } \\
\text { Apocynaceae } \\
\text { Kadakura }\end{array}$ & & & twice in day till cure diarrhoea. \\
\hline 47 & $\begin{array}{l}\text { Ipomoea aquatica } \\
\text { Forsk. } \\
\text { Convovulaceae } \\
\text { Haranvel }\end{array}$ & $\begin{array}{l}\text { Whole } \\
\text { plant }\end{array}$ & Galactagogue & $\begin{array}{l}100 \mathrm{gm} \text { whole plant mixed with fodder is } \\
\text { given daily to increase milk production. }\end{array}$ \\
\hline 48 & $\begin{array}{l}\text { Ipomoea fistulosa } \\
\text { Mart. } \\
\text { Convovulaceae } \\
\text { Beshrum }\end{array}$ & Leaves & Swelling & $\begin{array}{l}\text { Warm leaves are applied on swollen } \\
\text { area of body. }\end{array}$ \\
\hline 49 & $\begin{array}{l}\text { Jatropha curcas L. } \\
\text { Euphorbiaceae } \\
\text { Chandrajoti }\end{array}$ & Leaves & Wound & $\begin{array}{l}\text { The leaves are crushed on stone with } \\
\text { little amount of water to make a paste, it } \\
\text { is used as ointment on wound. }\end{array}$ \\
\hline 50 & $\begin{array}{l}\text { Lagascea mollis } \\
\text { Cav. } \\
\text { Asteraceae }\end{array}$ & Leaves & Wound & $\begin{array}{l}\text { Leaf extract is applied over the wound } \\
\text { till healing. }\end{array}$ \\
\hline \multirow[t]{2}{*}{51} & \multirow{2}{*}{$\begin{array}{l}\text { Lagenaria leucantha } \\
\text { (Duch.) } \\
\text { Cucurbitaceae } \\
\text { Kadubhopala }\end{array}$} & Fruit & Black quarter & $\begin{array}{l}250 \text { gm fruit pulp mixed with } 4 \mathrm{gm} \\
\text { camphor and } 1 / 2 \text { litre milk is given } 3 \\
\text { times in day to cure black quarter. }\end{array}$ \\
\hline & & Leaves & $\begin{array}{l}\text { Intestinal } \\
\text { worms }\end{array}$ & $\begin{array}{l}250 \mathrm{ml} \text { leaf juice is given orally for } 2 \\
\text { times in day for in case of intestinal } \\
\text { worms. }\end{array}$ \\
\hline 52 & $\begin{array}{l}\text { Leucaena latisiliqua } \\
\text { (L.) } \\
\text { Mimosaceae } \\
\text { Subabhul }\end{array}$ & Leaves & $\begin{array}{l}\text { Diarrhoea and } \\
\text { Dysentery }\end{array}$ & $\begin{array}{l}250 \text { gm leaves are pounded and mixed } \\
\text { with one litre water or butter milk. It is } \\
\text { given orally twice a day to cure } \\
\text { dysentery. }\end{array}$ \\
\hline \multirow[t]{2}{*}{53} & \multirow{2}{*}{$\begin{array}{l}\text { Linum usitatissimum } \\
\text { L. } \\
\text { Linaceae } \\
\text { Jawas }\end{array}$} & Oil & $\begin{array}{l}\text { Diarrhoea and } \\
\text { Dysentery }\end{array}$ & $\begin{array}{l}250 \mathrm{ml} \text { seed oil is given orally twice a } \\
\text { day to cure diarrhoea. }\end{array}$ \\
\hline & & Oil & Tympani & $250 \mathrm{ml}$ oil is given to cure tympani \\
\hline 54 & $\begin{array}{l}\text { Madhuca indica } \\
\text { Gmel. } \\
\text { Sapotaceae } \\
\text { Moh }\end{array}$ & Flowers & $\begin{array}{l}\text { Retention of } \\
\text { placenta }\end{array}$ & $\begin{array}{l}\text { The dried flowers mixed with jaggery is } \\
\text { given to cattle after delivery for removal } \\
\text { of placenta. }\end{array}$ \\
\hline 55 & $\begin{array}{l}\text { Martynia annua } \mathrm{L} \text {. } \\
\text { Martyniaceae } \\
\text { Waghnakhi }\end{array}$ & Fruit & Infertility & $\begin{array}{l}100 \mathrm{gm} \text { fruit powder mixed in } 1 \text { litre } \\
\text { water is given orally in case of infertility. }\end{array}$ \\
\hline 56 & $\begin{array}{l}\text { Medicago sativa L. } \\
\text { Papilionaceae } \\
\text { Lasun gavat }\end{array}$ & $\begin{array}{l}\text { Whole } \\
\text { plant }\end{array}$ & Galactagogue & $\begin{array}{l}\text { The animal is fed with Whole plant early } \\
\text { in the morning galactagogue. }\end{array}$ \\
\hline 57 & $\begin{array}{l}\text { Melia azedarach } \mathrm{L} . \\
\text { Meliaceae } \\
\text { Bakan }\end{array}$ & Leaves & $\begin{array}{l}\text { Diarrhoea and } \\
\text { Dysentery }\end{array}$ & $\begin{array}{l}\text { Leaves are fed with fodder to cure } \\
\text { dysentery. }\end{array}$ \\
\hline 58 & $\begin{array}{l}\text { Mentha spicata L. } \\
\text { Lamiaceae } \\
\text { Pudina }\end{array}$ & Leaves & $\begin{array}{l}\text { Diarrhoea and } \\
\text { Dysentery }\end{array}$ & $\begin{array}{l}250 \text { gm leaf paste mixed with } 1 / 2 \text { litre } \\
\text { buttermilk is given twice a day to cure } \\
\text { dysentery. }\end{array}$ \\
\hline 59 & Millettia auriculata & Root and & Ectoparasite & Root and stem juice is applied on body \\
\hline
\end{tabular}




\begin{tabular}{|c|c|c|c|c|}
\hline & $\begin{array}{l}\text { Baker } \\
\text { Papilionaceae }\end{array}$ & stem & (tick) & of cattle to remove ectoparasite (tick). \\
\hline 60 & $\begin{array}{l}\text { Mimosa pudica L. } \\
\text { Mimosaceae } \\
\text { Lajalu }\end{array}$ & Leaves & $\begin{array}{l}\text { Maggotted } \\
\text { wound }\end{array}$ & $\begin{array}{l}20 \text { gm fresh leaves are fed with jawar } \\
\text { bread (bhakari) twice a day to cure } \\
\text { maggotted wound. }\end{array}$ \\
\hline 61 & $\begin{array}{l}\text { Momordica } \\
\text { charantia L. } \\
\text { Cucurbitaceae } \\
\text { Karli }\end{array}$ & Leaves & $\begin{array}{l}\text { Blood } \\
\text { Dysentery }\end{array}$ & $\begin{array}{l}250 \mathrm{ml} \text { leaf decoction is given to cattle } \\
\text { twice a day to cure blood dysentery. }\end{array}$ \\
\hline 62 & $\begin{array}{l}\text { Murraya koenigii } \\
\text { (L.) } \\
\text { Rutaceae } \\
\text { Godnim }\end{array}$ & Leaves & $\begin{array}{l}\text { Diarrhoea and } \\
\text { Dysentery }\end{array}$ & $\begin{array}{l}100 \text { gm leaves pounded with butter milk } \\
\text { is given orally twice in day to cure } \\
\text { dysentery. }\end{array}$ \\
\hline 63 & $\begin{array}{l}\text { Musa paradisiaca } \mathrm{L} . \\
\text { Musaceae } \\
\text { Kela }\end{array}$ & Fruit & Galactagogue & $\begin{array}{l}\text { Fruit are fed with fodder to increase } \\
\text { lactation period. }\end{array}$ \\
\hline \multirow[t]{4}{*}{64} & \multirow{4}{*}{$\begin{array}{l}\text { Nicotiana tabacum } \\
\text { L. } \\
\text { Solanaceae } \\
\text { Tambakhu }\end{array}$} & Leaves & Wound & $\begin{array}{l}\text { Dried leaf powder mixed with lime and } \\
\text { jaggery is applied on wound. }\end{array}$ \\
\hline & & Leaves & $\begin{array}{l}\text { Ectoparasite } \\
\text { (tick) }\end{array}$ & $\begin{array}{l}\text { Decoction of dry leaves powder is } \\
\text { applied on body to removal of tick. }\end{array}$ \\
\hline & & \multirow[t]{2}{*}{ Leaves } & \multirow[t]{2}{*}{ Eye disease } & $\begin{array}{l}\text { After chewing dry leaves, saliva is spited } \\
\text { into the eye to cure eye disease }\end{array}$ \\
\hline & & & & $\begin{array}{l}\text { Dry leaves are soaked in water for 5-6 } \\
\text { hour and the filter use to wash eyes to } \\
\text { cure eye diseases. }\end{array}$ \\
\hline \multirow[t]{2}{*}{65} & \multirow{2}{*}{$\begin{array}{l}\text { Nyctanthes arbor- } \\
\text { tristis L. } \\
\text { Oleaceae } \\
\text { Parijatak }\end{array}$} & Leaves & $\begin{array}{l}\text { Foot and } \\
\text { mouth diseases }\end{array}$ & $\begin{array}{l}\text { Infusion of } 1 \mathrm{~kg} \text { leaves is given orally } \\
\text { twice a day to cure mouth disease. }\end{array}$ \\
\hline & & Leaves & Wound & $\begin{array}{l}\text { Fresh leaves along with turmeric powder } \\
\text { ground to form a paste are applied on the } \\
\text { wound. }\end{array}$ \\
\hline 66 & $\begin{array}{l}\text { Ocimum sanctum } \mathrm{L} \text {. } \\
\text { Lamiaceae } \\
\text { Tulasi }\end{array}$ & Leaves & Wound & Leaf paste is applied on wound. \\
\hline \multirow[t]{2}{*}{67} & \multirow{2}{*}{$\begin{array}{l}\text { Oroxylum indicum } \\
\text { (L.) } \\
\text { Bignoniaceae } \\
\text { Tetu }\end{array}$} & Bark & Black quarter & $\begin{array}{l}200 \text { gm bark pounded with } 1 / 2 \text { litre butter } \\
\text { milk is given orally twice in day to cure } \\
\text { black quarter. }\end{array}$ \\
\hline & & Stem & $\begin{array}{l}\text { Diarrhoea and } \\
\text { Dysentery }\end{array}$ & $\begin{array}{l}\text { Stem crushed with water is given twice a } \\
\text { day to cure diarrhea and dysentery. }\end{array}$ \\
\hline 68 & $\begin{array}{l}\text { Ougeinia oojeinensis } \\
\text { (Roxb.) } \\
\text { Papilionaceae } \\
\text { Ruthu }\end{array}$ & $\begin{array}{l}\text { Stem } \\
\text { bark }\end{array}$ & Diarrhoea & $\begin{array}{l}250 \text { gm stem bark paste put overnight in } \\
\text { water and extract is given twice in day to } \\
\text { cure diarrhoea. }\end{array}$ \\
\hline 69 & $\begin{array}{l}\text { Pergularia daemia } \\
\text { (Forssk.) } \\
\text { Asclepidaceae } \\
\text { Utaran }\end{array}$ & $\begin{array}{l}\text { Whole } \\
\text { plant }\end{array}$ & Black quarter & $\begin{array}{l}250 \mathrm{ml} \text { plant extract is given orally twice } \\
\text { in a day to cure black quarter. }\end{array}$ \\
\hline 70 & $\begin{array}{l}\text { Phyllanthus amarus } \\
\text { Schumach \& Thonn. }\end{array}$ & $\begin{array}{l}\text { Whole } \\
\text { plant }\end{array}$ & $\begin{array}{l}\text { Diarrhoea and } \\
\text { Dysentery }\end{array}$ & $\begin{array}{l}\text { Whole plant is fed with fodder to cure } \\
\text { dysentery. }\end{array}$ \\
\hline
\end{tabular}




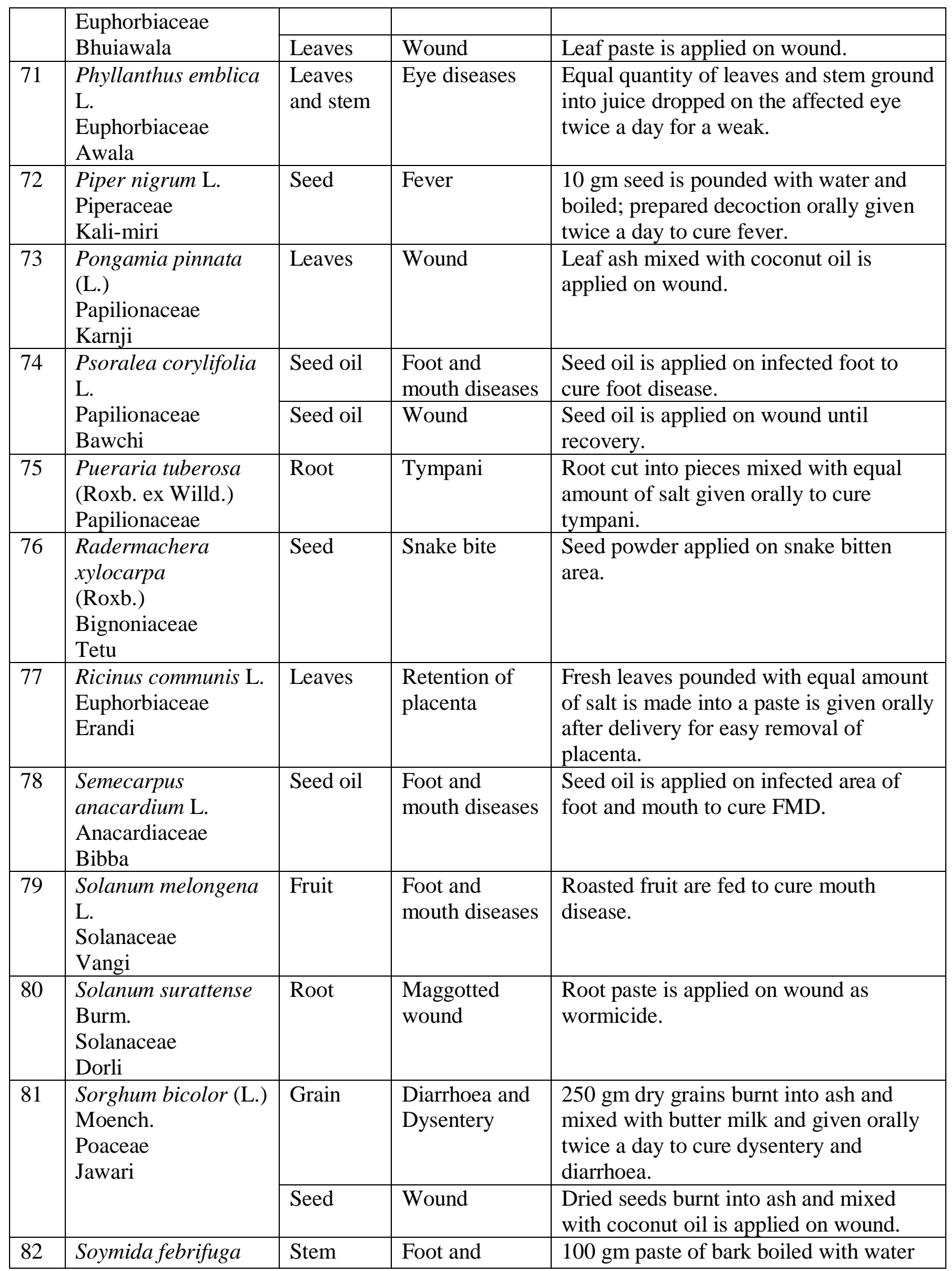




\begin{tabular}{|c|c|c|c|c|}
\hline & $\begin{array}{l}\text { (Roxb.) } \\
\text { Meliaceae } \\
\text { Rohini }\end{array}$ & bark & mouth diseases & $\begin{array}{l}\text { and prepared extract is applied on foot to } \\
\text { cure foot disease. }\end{array}$ \\
\hline \multirow[t]{2}{*}{83} & \multirow{2}{*}{$\begin{array}{l}\text { Syzygium cumini }(\mathrm{L} .) \\
\text { Skeels. } \\
\text { Myrtaceae } \\
\text { Jamun }\end{array}$} & $\begin{array}{l}\text { Stem } \\
\text { bark }\end{array}$ & $\begin{array}{l}\text { Diarrhoea and } \\
\text { Dysentery }\end{array}$ & $\begin{array}{l}100 \text { gm stem bark crushed and soaked } \\
\text { overnight in water is given twice a day to } \\
\text { cure dysentery. }\end{array}$ \\
\hline & & $\begin{array}{l}\text { Stem } \\
\text { bark }\end{array}$ & Haematuria & $\begin{array}{l}50 \text { gm of bark powder mixed with } 250 \\
\mathrm{ml} \text { ghee and } 1 / 2 \text { litre curd is given orally } \\
\text { twice in day to cure haematuria. }\end{array}$ \\
\hline 84 & $\begin{array}{l}\text { Tamarindus indica } \\
\text { L. } \\
\text { Caesalpiniaceae } \\
\text { Chinch }\end{array}$ & Leaves & Bone fracture & $\begin{array}{l}\text { Fresh leaf paste and equal amount of ant } \\
\text { heap soil mixed with warm water is } \\
\text { applied on bone fracture area to cure } \\
\text { fracture. }\end{array}$ \\
\hline 85 & $\begin{array}{l}\text { Tectona grandis L. } \\
\text { Verbenaceae } \\
\text { Sag }\end{array}$ & Leaves & Wound & Leaf paste is applied on wound. \\
\hline 86 & $\begin{array}{l}\text { Terminalia arjuna } \\
\text { (Roxb.) } \\
\text { Combretaceae } \\
\text { Arjun }\end{array}$ & $\begin{array}{l}\text { Stem } \\
\text { bark }\end{array}$ & Bone fracture & $\begin{array}{l}\text { The stem bark paste is smeared over the } \\
\text { fractured area to treat bone fracture. }\end{array}$ \\
\hline 87 & $\begin{array}{l}\text { Trachyspermum } \\
\text { ammi (L.) } \\
\text { Apiaceae } \\
\text { Ova }\end{array}$ & Seed & Fever & $\begin{array}{l}50 \mathrm{gm} \text { seed powder mixed with milk is } \\
\text { given orally twice a day to cure fever. }\end{array}$ \\
\hline 88 & $\begin{array}{l}\text { Tragia hildebrandtii } \\
\text { Muell.-Arg. } \\
\text { Euphorbiaceae } \\
\text { Agya }\end{array}$ & Root & $\begin{array}{l}\text { Maggotted } \\
\text { wound }\end{array}$ & Root paste is applied on maggot wound. \\
\hline 89 & $\begin{array}{l}\text { Vernonia } \\
\text { anthelmintica }(\mathrm{L}) \\
\text { Asteracae } \\
\text { Kadujira }\end{array}$ & Seed & $\begin{array}{l}\text { Intestinal } \\
\text { worm }\end{array}$ & $\begin{array}{l}20 \text { gm seed powder is boiled with one } \\
\text { liter is given orally to cure intestinal } \\
\text { worm. }\end{array}$ \\
\hline \multirow[t]{2}{*}{90} & \multirow[t]{2}{*}{$\begin{array}{l}\text { Vigna radiata }(\mathrm{L} .) \\
\text { Papilionaceae } \\
\text { Mung }\end{array}$} & Seed & $\begin{array}{l}\text { Foot and } \\
\text { mouth diseases }\end{array}$ & $\begin{array}{l}1 / 2 \mathrm{~kg} \text { seeds soaked overnight in water is } \\
\text { given orally to cure foot and mouth } \\
\text { disease. }\end{array}$ \\
\hline & & Seed & $\begin{array}{l}\text { Diarrhoea and } \\
\text { Dysentery }\end{array}$ & $\begin{array}{l}1 / 2 \mathrm{~kg} \text { seeds soaked in water is given with } \\
\text { fodder to cure diarrhoea. }\end{array}$ \\
\hline 91 & $\begin{array}{l}\text { Vitex negundo L. } \\
\text { Verbenaceae } \\
\text { Sambalu }\end{array}$ & Leaves & Eye diseases & $\begin{array}{l}\text { Juice of the leaves is dropped into eye to } \\
\text { cure diseases. }\end{array}$ \\
\hline 92 & $\begin{array}{l}\text { Wrightia tinctoria } \mathrm{R} . \\
\text { Br. } \\
\text { Apocynaceae } \\
\text { Dudhkadi }\end{array}$ & Fruit & Galactagogue & $\begin{array}{l}\text { Fruit are fed to cattle daily to increase } \\
\text { lactation. }\end{array}$ \\
\hline 93 & $\begin{array}{l}\text { Xanthium } \\
\text { strumarium L. } \\
\text { Asteraceae } \\
\text { Gokharu }\end{array}$ & Leaves & Wound & Leaf paste is applied on wound. \\
\hline
\end{tabular}




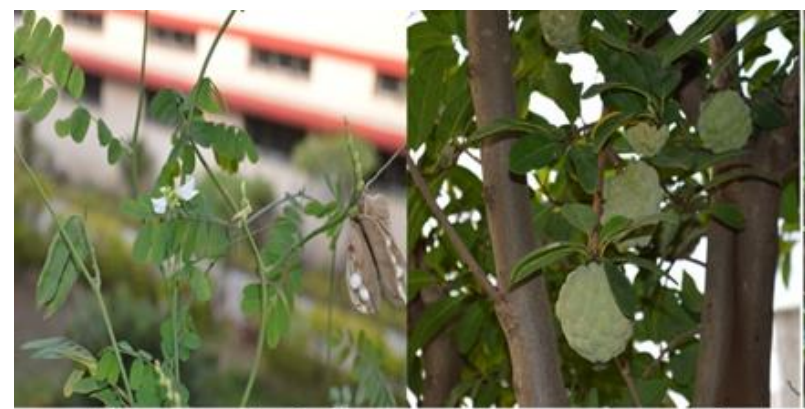

Abrus precatorius $\mathrm{L}$.

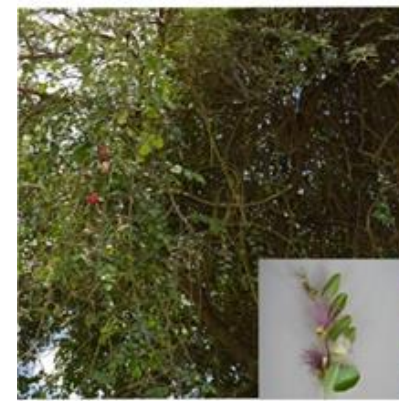

Capparis zeylanica $\mathrm{L}$.

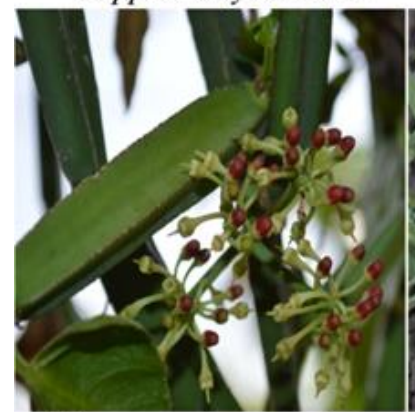

Cissus quadrangularis $\mathrm{L}$.
Annona squamosa $\mathrm{L}$.

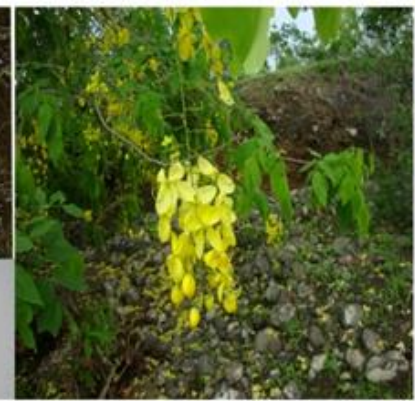

Cassia fistula $\mathrm{L}$.

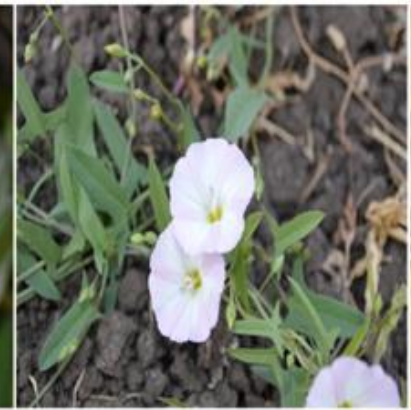

Convolvulus arvensis $\mathrm{L}$.

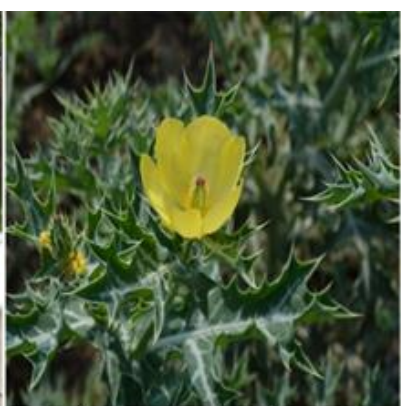

Argemone mexicana L.

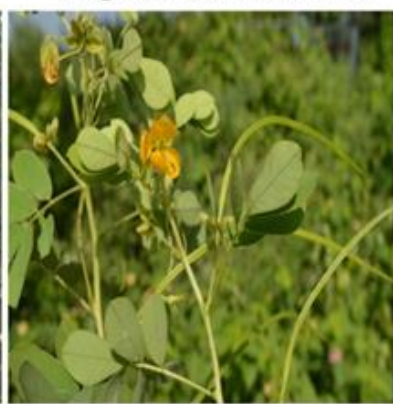

Cassia obtusifolia L.

DOI: 10.5281/zenodo.1165289

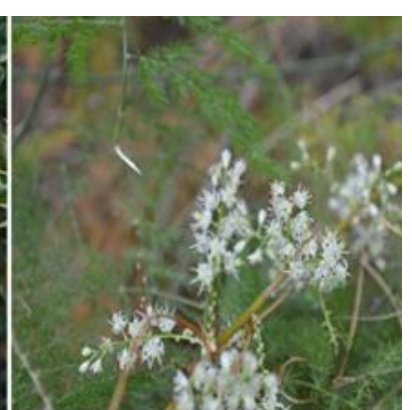

Asparagus racemosus Willd.

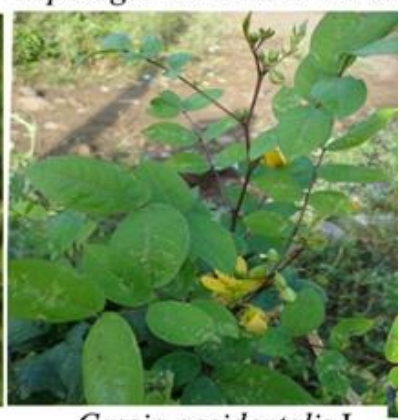

Cassia occidentalis L.
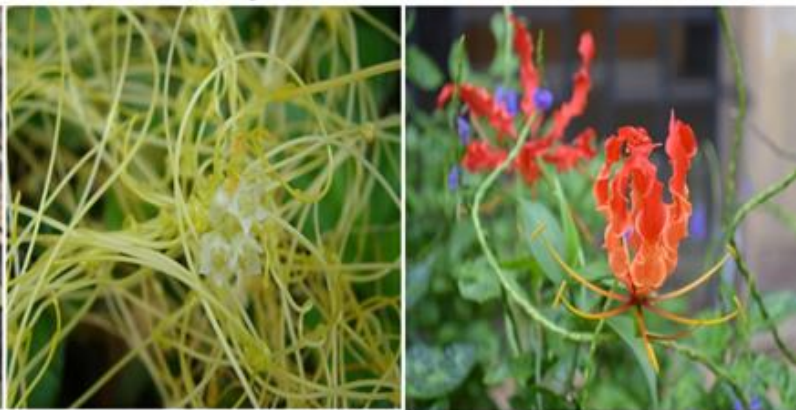

Cuscuta chinensis Lamk.

Gloriosa superba L.

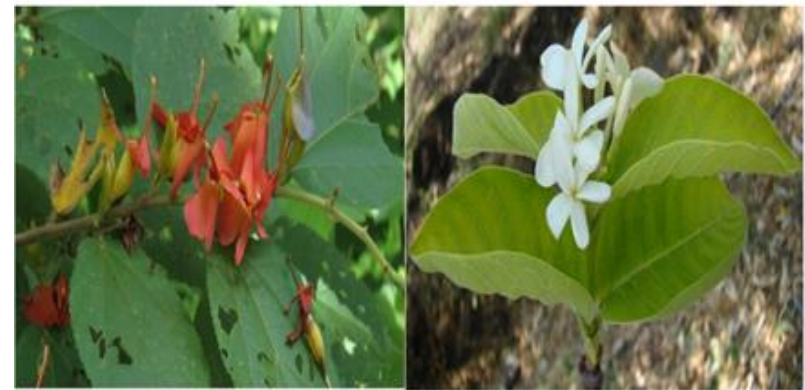

Helicteres isora $\mathrm{L}$.

Holarrhena pubescens (Buch-Ham)
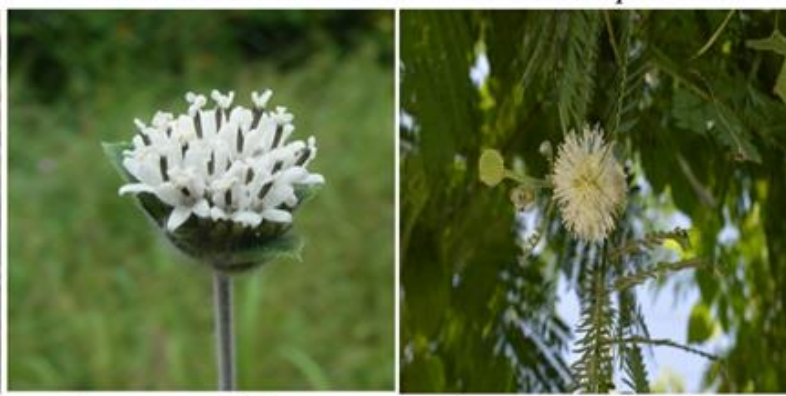

Lagascea mollis Cav.

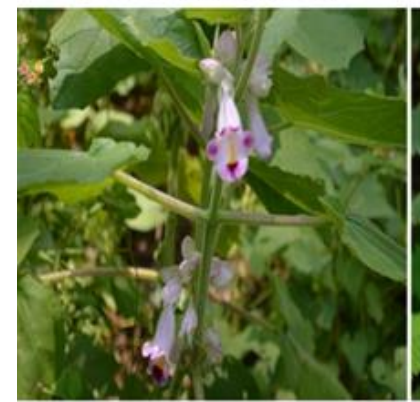

Martynia aпnиa $\mathrm{L}$.

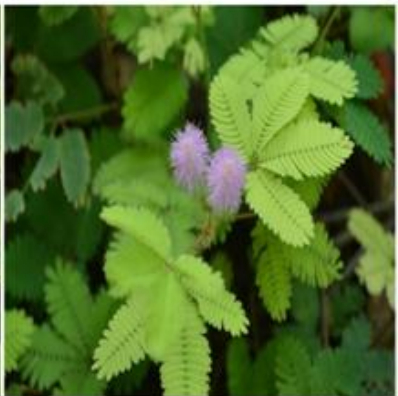

Mimosa pudica $\mathrm{L}$.

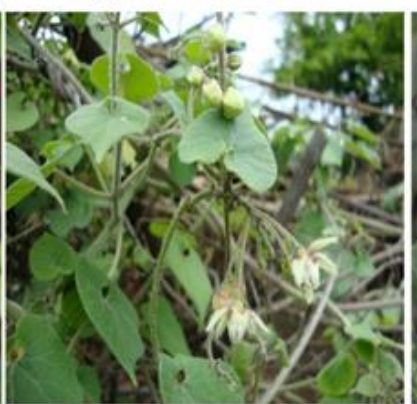

Pergularia daemia (Forssk.)
Leucaena latisiliqua (L.)

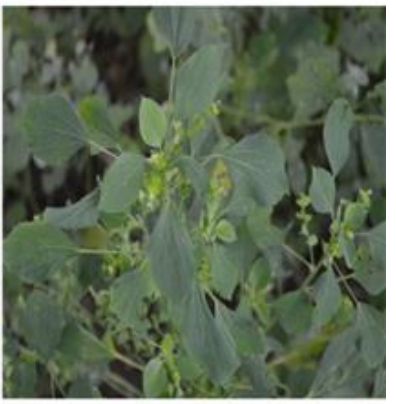

Phyllanthus amarus

Schumach \& Thonn. 


\section{Conclusion}

The present study have explored interesting data on the plants used in traditional veterinary practices, which provides scope for further pharmacognostic and pharmacological studies to understand the potential in these plant based crude drugs. Folk ethnoveterinary practices largely remain neglected and little has been done to document this precious wealth hence there is urgent need to document it on scientific line. Therefore, the documentation of such knowledge is very crucial before its extinction for the utilization of community and for the further scientific validation. There is need for proper analysis of medicinal plants to relate the authenticity of these drugs. Ethnoveterinary medicine can provide an opportunity for new drug development.

\section{Acknowledgement}

Authors express their sincere thanks to the tribals and rural people of the area for providing valuable information about veterinary practices. Authors are also thankful to the Head, Botany department, GVISH Amravati and Dr. S.S. Yawale, Director, GVISH Amravati for providing necessary facilities valuable suggestions. One of the authors (SMJ) is thankful to the University Grant Commission- New Delhi UGC India for financial assistance in the form of Junior Research Fellowship.

\section{References}

[1] Cook, T. (1967). "The Flora of the Presidency of Bombay." Vol. I, II, III. Calcutta: Botanical Survey of India. (Rpr.)

[2] Balaji, S. N. And Chakravati V. P. (2010). Ethnoveterinary practices in India- A review. Veterinary World. 3.12, 549-551.

[3] Mc Corkle, C.M. (1986). An introduction to ethnoveterinary research and development. J Ethnobiol. 6, 129-149.

[4] Naik,V.N. (1998). The flora of Marathawada. Aurngabad: Amrut prakashan.

[5] Roy, Burmen, J.J. (2003). Tribal medicine. New Dehli: Mittal Publications.

[6] Singh, N.P. and Karthikeyan, S. (2000). Flora of Maharashtra State. Vol. I, II, III. Calcutta: Botanical Survey of India.

*Corresponding author.

E-mail address: sangeetajambu23@ gmail.com 